ISSN 0258-7122 (Print), 2408-8293 (Online)

Bangladesh J. Agril. Res. 44(4): 659-668, December 2019

\title{
EFFECT OF POTASSIUM ON YIELD, QUALITY AND SHELF LIFE OF TOMATO
}

\author{
M. S. ISLAM ${ }^{1}$, M. ZAKARIA ${ }^{2}$, M. M. HOSSAIN ${ }^{3}$ \\ M. A. B. MIA ${ }^{4}$ AND A. J. M. S. KARIM ${ }^{5}$
}

\begin{abstract}
The experiment was conducted at the experimental field of the Department of Horticulture, Bangabandhu Sheikh Mujibur Rahman Agricultural University (BSMRAU), Salna, Gazipur, to study the effect of potassium on yield, quality and shelf life of tomato under ambient condition during 15 October 2015 to 30 June 2016. Six levels of K viz., 0, 35, 70, 105, 140 and $175 \mathrm{~kg} / \mathrm{ha}$ consisted of the treatments of the experiment. The tomato plant treated with $\mathrm{K}_{105}$ produced maximum plant height $(128.50 \mathrm{~cm})$, number of fruits plant ${ }^{-1}(26.49)$, fruit diameter $(5.71 \mathrm{~cm})$, fruit length $(5.83 \mathrm{~cm})$, weight of fruits plant ${ }^{-1}(1.72 \mathrm{~kg})$, fruit yield $\mathrm{ha}^{-1}(71.96$ ton), dry matter $(7.56 \%)$, firmness $(1.22 \mathrm{~N})$, shelf life $(15$ days), TSS $(10.30 \%), \beta$ carotene $(0.090 \mathrm{mg} / 100 \mathrm{~g})$, ascorbic acid $(26.49 \mathrm{mg} / 100$ $\mathrm{g})$ and total sugar $(5.05 \%)$. Contents of iron $(123.20 \mathrm{ppm})$, calcium $(0.42 \%)$ and potassium $(0.71 \%)$ were recorded maximum in $\mathrm{K}_{140}, \mathrm{~K}_{35}$ and $\mathrm{K}_{175}$ respectively. Iron and potassium content increased with the increasing level of potassium but reverse effect was found in case of calcium. The regression equation for applied $\mathrm{K}$ were $\mathrm{Y}=-3.339 \mathrm{x}^{2}+636.5 \mathrm{x}+42606$. Based on this equation, the optimum dose of $\mathrm{K}$ for tomato was $95.31 \mathrm{~kg} \mathrm{ha}^{-1}$ in salna series of shallow red brown terrace soil and its corresponding yield is $71.96 \mathrm{t} \mathrm{ha}^{-1}$.
\end{abstract}

Keywords: Potassium, yield, quality and shelf life, tomato.

\section{Introduction}

Tomato (Solanum lycopersicum) is one of the most important vegetable crops grown throughout the world under field and green house conditions (Kaloo, 1986). In terms of human health, tomato is a major component in the daily diet in many countries and constitutes an important source of minerals, vitamins, and antioxidants (Grierson and Kader, 1986). The global production area for tomato was estimated at $44,12,757$ ha with world production quantity estimated at $15,16,99,405$ metric tons and global yield was estimated $34.38 \mathrm{t} / \mathrm{ha}$ (FAO, 2010). The area of tomato in Bangladesh is 26,316 ha and production is 2,50,947 metric tons. While the yield is $9.54 \mathrm{t} / \mathrm{ha}$ (BBS, 2013) which is relatively very low in Bangladesh as compared to other tomato producing countries (Vanitha et al., 2013).

${ }^{1}$ Deputy Secretary, Ministry of Industries, ${ }^{2 \& 3}$ Department of Horticulture, ${ }^{4}$ Department of Crop Botany, ${ }^{5}$ Department of Soil Science, Bangabandhu Sheikh Mujibur Rahman Agricultural University (BSMRAU), Salna, Gazipur- 1706, Bangladesh. 
Tomato is a highly perishable vegetable with limited shelf life and can be kept very short period in room temperature. The post harvest loss reported upto $32.90 \%$ in tomato (Hassan et al., 2010). Moreover, it grows in Bangladesh mainly in winter period which lead to market glut in season. Adequate supply of nutrient can increase the yield, fruit quality, fruit size, keeping quality, colour and taste of tomato (Shukla and Naik, 1993). Concerning plant nutrition, potassium plays an important role in the improvement of post harvest quality traits in tomato (Cakmak, 2005). Adequate $\mathrm{K}$ nutrition has also been associated with increased yield, fruit size, increased soluble solids and ascorbic acid concentrations, improved fruit colour, increased shelf life and shipping quality of many horticultural crops (Lester et al., 2007). Potassium act like a spark-plug for activation of more than 60 enzymes which needs improvement of yield and quality of plant (Malvi, 2011). So application of proper doses of potassium is of great importance.

But little specific work has been carried out in Bangladesh condition to investigate the effect of potassium on yield, quality and self life improvement of tomato. Considering the above facts, the present study was undertaken to find out the optimum dose of potassium for yield, quality and shelf life improvement of tomato.

\section{Materials and Methods}

The experiment was conducted at the experimental field of Horticulture and at the laboratory of Horticulture and Soil Science Department of Bangabandhu Sheikh Mujibur Rahman Agricultural University (BSMRAU), Salna, Gazipur, Bangladesh during October 2015 to June 2016. Six levels of potassium viz. $\mathrm{T}_{0}=$ $\mathrm{K}_{0}\left(0 \mathrm{~kg} \mathrm{MoP} \mathrm{ha}^{-1}\right), \mathrm{T}_{1}=\mathrm{K}_{35}\left(70 \mathrm{~kg} \mathrm{MoP} \mathrm{ha}^{-1}\right), \mathrm{T}_{2}=\mathrm{K}_{70}(140 \mathrm{~kg}$ MoP ha$\left.{ }^{1}\right), \mathrm{T}_{3}=\mathrm{K}_{105}\left(210 \mathrm{~kg} \mathrm{MoP} \mathrm{ha}{ }^{-1}\right), \mathrm{T}_{4}=\mathrm{K}_{140}\left(280 \mathrm{~kg} \mathrm{MoP} \mathrm{ha}^{-1}\right)$ and $\mathrm{T}_{5}=\mathrm{K}_{175}(350 \mathrm{~kg}$ MoP $\mathrm{ha}^{-1}$ ) consisted of the treatments of the experiment. The treatments were selected on the basis of initial soil test value. The soil contained $1.06 \%$ organic matter, $0.114 \%$ total nitrogen, $3.70 \mu \mathrm{g} / \mathrm{g}$ available phosphorus, $0.11 \mathrm{meq} / 100 \mathrm{~g}$ exchangeable potassium, $12.00 \mathrm{ppm}$ sulphur, $1.30 \mu \mathrm{g} / \mathrm{g}$ zinc and $0.20 \mathrm{ppm}$ available boron. The experiment was laid out in a Randomized Complete Block Design (RCBD) with four replications. The dimension of each plot was $1.8 \times 2$ $\mathrm{m}$. The unit plots and blocks were separated by $0.50 \mathrm{~m}$ and $1.0, \mathrm{~m}$ respectively. The selected land was prepared in October 2015 by tractor drawn plough followed by harrowing and laddering. The plots were prepared, drains were made around each plot and the excavated soil was used for raising the plots about 10 $\mathrm{cm}$ high from the soil surface. Other fertilizers were applied @ 10000-126-64-122-1 kgha $^{-1}$ of Cowdung-N-P-S-Zn-B. Doses of fertilizer were calculated according to Fertilizer Recommendation Guide (FRG, 2012). Full doses of well decomposed cowdung, $\mathrm{P}, \mathrm{S}, \mathrm{Zn}, \mathrm{B}, 50 \%$ potassium were applied as basal dose and were incorporated into the prepared plots a few days before planting. 
Remaining 50\% potassium and full dose of urea were applied in two splits after 20 and 40 days of transplanting. Seeds of tomato variety BARI Tomato-14 were collected from the Horticulture Research Centre of BARI, Gazipur. Seeds were sown in plastic trays on 26 October, 2015 in $2-3 \mathrm{~cm}$ deep furrows at $10 \mathrm{~cm}$ apart rows. Seedlings emerged between 3-4 days after sowing. After 5 days of germination, seedlings were transferred into poly bags. Twenty days old seedlings were transplanted in the experimental field on 20 November, 2015 at $60 \mathrm{~cm}$ row to row and $40 \mathrm{~cm}$ plant to plant distance.

Necessary intercultural operations such as weeding, staking, pruning, irrigation and mulching were done as and when necessary during the crop growing period. Admire 20 SL @ $0.5 \mathrm{ml} / 1$, dithane M-45 @ $2.5 \mathrm{~g} / \mathrm{l}$ of water was applied to control insect pest and fungus diseases. Tomato was harvested at breaker stage from randomly selected 10 plants of each plot. Data on plant height, number of fruit per plant, fruit diameter and length, weight of fruit per plant were recorded in the field at last harvest and yield per hectare were estimated from plot yield. The following chemical and nutritive components were recorded after harvesting.

\section{Determination of shelf life (days)}

Days required from harvest to ripening (marketable condition) under ambient condition.

\section{Weight loss (\%)}

Loss of weight were estimated by the following formula

Percent weight loss $=\frac{\text { Initial weight }- \text { Final weight }}{\text { Initalweight }} \times 100$

\section{Determination of moisture percent $(\%)$}

Moisture percent was calculated according to the following formula:

Moisture percent $=\frac{\text { Fresh weight }- \text { Dry weight }}{\text { Fresh weight }} \times 100$

\section{Dry matter (\%)}

Dry matter percent of tomato was calculated according to the following formula:

Dry matter percent $=\frac{\text { Dry weight of pulp }}{\text { Fresh weight of pulp }} \times 100$

\section{Total soluble solids (\%)}

Total soluble solids were determined by an ATAGO NT hand refractometer and expressed in percentage. 


\section{Firmness (N)}

Firmness was determined by using Fruit Texture Analyzer (Guss, Model No. GS25, SA) supported by FTA win software. Results were expressed in Newton (N).

\section{Nutrient content analysis}

Ascorbic acid was determined as per Pleshkov (1976), $\beta$ - carotene was calculated according to Nagata et al., (1992), total sugar was estimated according to bertrand method and mineral elements viz. iron, calcium, potassium as described by Piper (1966)

\section{Statistical analysis}

The recorded data were statistically analyzed by using MSTAT-C software and mean were compared by DMRT at $5 \%$ or $1 \%$ level of probability.

\section{Results and Discussion}

\section{Plant height}

Different doses of potassium had no significant effect on plant height (Table 1).The tallest plant was found in $K_{105}(128.50 \mathrm{~cm})$ and it was followed by $K_{70}$ $(128.00 \mathrm{~cm}) \mathrm{K}_{35}(127.50 \mathrm{~cm})$ and $\mathrm{K}_{140}(127.30 \mathrm{~cm})$. The shortest plant height was found in $\mathrm{K}_{175}(125.50 \mathrm{~cm})$. Similar opinion was also express by Bhagat et al. (2014) who found the tallest tomato plant in $100 \mathrm{~kg} \mathrm{~K} \mathrm{ha}^{-1}$.

\section{Number of fruits per plant}

Different doses of potassium had significant effect on number of fruit per plant (Table 1). The highest number of fruit per plant was observed in $K_{105}$ (26.49) which was statistically alike to $\mathrm{K}_{70}$ (26.01). On the other hand, the plants under control $\left(\mathrm{K}_{0}\right)$ gave the lowest number of fruit (17.60) per plant. Similar result was also reported by Bhagat et al., (2014) who found the highest number of tomato per plant with $100 \mathrm{~kg} \mathrm{~K} \mathrm{ha}^{-1}$.

\section{Fruit diameter}

Significant variation in fruit diameter $(\mathrm{cm})$ was found due to the effect of potassium (Table 1). The highest fruit diameter $\left(5.71 \mathrm{~cm}\right.$ ) was found in $\mathrm{K}_{105}$ which was statistically similar to $K_{70}(5.63 \mathrm{~cm})$ and it was minimum $(4.68 \mathrm{~cm})$ in $\mathrm{K}_{0}$. The results were in line with the report of Mazed et al., (2015) who found maximum diameter of fruit from $140 \mathrm{~kg} \mathrm{~K} \mathrm{ha}^{-1}$ and minimum from control $\left(\mathrm{K}_{0}\right)$.

\section{Fruit length}

Highest fruit length was recorded in $\mathrm{K}_{105}(5.83 \mathrm{~cm})$ and it was statistically similar to $\mathrm{K}_{70}(5.71 \mathrm{~cm}), \mathrm{K}_{35}(5.50)$ and $\mathrm{K}_{140}(5.51 \mathrm{~cm})$. On the contrary, the fruit length 
was the minimum $(5.05 \mathrm{~cm})$ in $\mathrm{K}_{175}$. Optimum potassium influenced nutrient absorption capacity of plant that encouraged cell division, hormonal and enzymatic activities resulting higher fruit length.

\section{Fruit yield per plant}

Significant variation of yield per plant was found due to the influence of potassium (Table 1). The maximum yield was observed in $\mathrm{K}_{105}(1.72 \mathrm{~kg})$ which was statistically alike to $\mathrm{K}_{70}(1.68 \mathrm{~kg})$ and it was minimum in $\mathrm{K}_{0}(0.99 \mathrm{~kg})$.

\section{Fruit yield per hectare}

The highest yield was recorded in treatment $\mathrm{K}_{105}$ (71.96) which was statistically similar to $\mathrm{K}_{70}$ (70.34). The lowest yield was recorded in $\mathrm{K}_{0}$ (41.25) (Table 1). Bhagat et al., (2014) also reported that $100 \mathrm{~kg} \mathrm{~K} / \mathrm{ha}$ gave the highest yield in tomato. Usherwood (1985) reported that adequate $\mathrm{K}$ fertilizer involved in photophosphorylation, transportation of photoassimilates from source tissues via the phloem to sink tissues, enzymes activation, turgor maintenance and stress tolerance resulting in higher yield.

Table 1. Yield and physical characteristics of tomato in response of potassium

\begin{tabular}{l|c|c|c|c|c|c|c|c|c}
\hline Level of K & $\begin{array}{c}\text { Plant } \\
\text { height } \\
(\mathrm{cm})\end{array}$ & $\begin{array}{c}\text { No. of } \\
\text { fruit/plant }\end{array}$ & $\begin{array}{c}\text { Fruit } \\
\text { diameter } \\
(\mathrm{cm})\end{array}$ & $\begin{array}{c}\text { Fruit } \\
\text { length } \\
(\mathrm{cm})\end{array}$ & $\begin{array}{c}\text { Fruit } \\
\text { yield } \\
(\mathrm{kg} \\
\left.\text { plant }{ }^{-1}\right)\end{array}$ & $\begin{array}{c}\text { Fruit } \\
\text { yield } \\
\left(\mathrm{t} \mathrm{ha}^{-1}\right)\end{array}$ & $\begin{array}{c}\text { Dry } \\
\text { matter } \\
(\%)\end{array}$ & $\begin{array}{c}\text { Firmness } \\
(\mathrm{N})\end{array}$ & $\begin{array}{c}\text { Weight } \\
\text { loss (\%) }\end{array}$ \\
\hline $\mathrm{K}_{0}$ & $126.17 \mathrm{c}$ & $17.60 \mathrm{e}$ & $4.68 \mathrm{c}$ & $5.31 \mathrm{~b}$ & $0.99 \mathrm{e}$ & $41.25 \mathrm{e}$ & $5.41 \mathrm{c}$ & $0.90 \mathrm{c}$ & $12.24 \mathrm{a}$ \\
$\mathrm{K}_{35}$ & $127.50 \mathrm{~b}$ & $23.63 \mathrm{c}$ & $5.21 \mathrm{~b}$ & $5.50 \mathrm{ab}$ & $1.49 \mathrm{c}$ & $62.39 \mathrm{c}$ & $6.13 \mathrm{~b}$ & $1.10 \mathrm{ab}$ & $10.76 \mathrm{~b}$ \\
$\mathrm{~K}_{70}$ & $128.00 \mathrm{ab}$ & $26.01 \mathrm{ab}$ & $5.63 \mathrm{ab}$ & $5.71 \mathrm{ab}$ & $1.68 \mathrm{a}$ & $70.34 \mathrm{a}$ & $7.29 \mathrm{a}$ & $1.17 \mathrm{ab}$ & $9.36 \mathrm{bc}$ \\
$\mathrm{K}_{105}$ & $128.50 \mathrm{a}$ & $26.49 \mathrm{a}$ & $5.71 \mathrm{a}$ & $5.83 \mathrm{a}$ & $1.72 \mathrm{a}$ & $71.96 \mathrm{a}$ & $7.56 \mathrm{a}$ & $1.22 \mathrm{a}$ & $8.36 \mathrm{c}$ \\
$\mathrm{K}_{140}$ & $127.30 \mathrm{~b}$ & $25.08 \mathrm{~b}$ & $5.42 \mathrm{~b}$ & $5.51 \mathrm{ab}$ & $1.59 \mathrm{~b}$ & $66.33 \mathrm{~b}$ & $7.47 \mathrm{a}$ & $1.07 \mathrm{~b}$ & $10.05 \mathrm{bc}$ \\
$\mathrm{K}_{175}$ & $125.50 \mathrm{c}$ & $21.46 \mathrm{~d}$ & $4.78 \mathrm{c}$ & $5.05 \mathrm{c}$ & $1.24 \mathrm{~d}$ & $51.91 \mathrm{~d}$ & $6.27 \mathrm{~b}$ & $0.92 \mathrm{c}$ & $10.76 \mathrm{~b}$ \\
\hline $\begin{array}{l}\text { Level of } \\
\text { significance }\end{array}$ & $* *$ & $* *$ & $* *$ & $* *$ & $* *$ & $* *$ & $* *$ & $* *$ & $* *$ \\
$\mathrm{CV}(\%)$ & 4.49 & 3.43 & 3.02 & 3.75 & 3.69 & 3.63 & 4.84 & 7.91 & 3.12 \\
\hline
\end{tabular}

Means bearing same letter (s) do not differ significantly at $1 \%$ level of probability by DMRT.

** $1 \%$ level of probability.

\section{Dry matter}

Dry matter content of tomato varied significantly at different doses of potassium (Table 1). The highest dry matter was recorded in $\mathrm{K}_{105}(7.56 \%)$ which was statistically similar to $\mathrm{K}_{140}(7.47 \%)$ and $\mathrm{K}_{70}(7.29 \%)$. The lowest dry matter was 
found in $\mathrm{K}_{0}(5.41 \%)$. This might be due to optimum supply of potassium that increased photosynthesis and translocation of photosynthetic from source to sink.

\section{Firmness}

Firmness varied significantly with the different levels of potassium (Table1). The highest firmness $(1.22 \mathrm{~N})$ was found in $\mathrm{K}_{105}$ which was statistically similar to $\mathrm{K}_{70}$ $(1.17 \mathrm{~N})$ and $\mathrm{K}_{35}(1.10 \mathrm{~N})$ While $\mathrm{K}_{0}$ showed the lowest firmness $(0.90 \mathrm{~N})$. Potassium may helped in increase fibre and lignin formation that resulted in more compactness of fruit.

\section{Weight loss}

Significant variation of weight loss (\%) was found due to different doses of potassium at ambient condition (Table 1). However, maximum weight loss $(12.24 \%)$ was found in $\mathrm{K}_{0}$. The minimum weight loss was found in $\mathrm{K}_{105}(8.36 \%)$ which was statistically identical with $\mathrm{K}_{70}(9.36 \%)$ and $\mathrm{K}_{140}(10.05 \%)$.

\section{Shelf life}

Shelf life of tomato varied significantly with the different rate of potassium (Fig 1.). The highest shelf life ( 15 days) was found in $K_{105}$. On the contrary, the lowest shelf life was found in $\mathrm{K}_{0}$ (9 days). With optimum $\mathrm{K}$ nutrition, fruit is generally higher in total solids, sugars, acid, carotene and lycopene content and has a better keeping quality (Munson, 1985). Optimum dose of $\mathrm{K}$ may promote the development of thicker outer wall by producing lignin in the epidermal cells to prevent disease attack and increase shelf life.

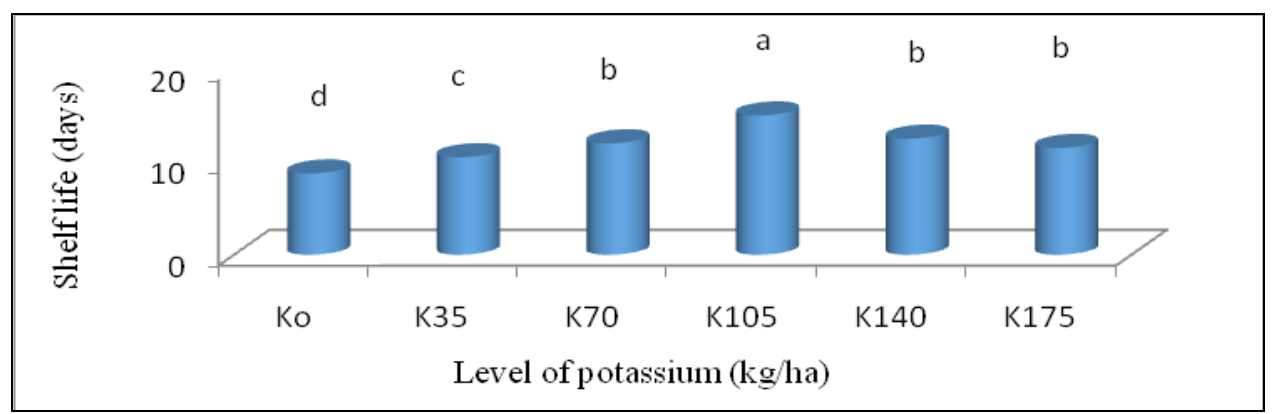

Fig. 1. Influence of potassium on shelf life (days) of tomato.

(Means bearing same letter (s) do not differ significantly at 0.05 level by DMRT).

\section{Total soluble solids}

Potassium had significant influence on total soluble solids (Table 2). The highest TSS $(10.30 \%)$ was found in $K_{105}$ which was statistically similar with $K_{70}$. whereas the lowest was found in $\mathrm{K}_{0}(9.17 \%)$. These results are in line with Cakmak (2005). He reported increasing trend of sugar contents as well as TSS in tomato with $\mathrm{K}$ fertilizer application. 
Table 2. Nutritive quality of tomato in response of potassium

\begin{tabular}{|c|c|c|c|c|c|c|c|}
\hline Level of $\mathrm{K}$ & $\begin{array}{l}\text { TSS } \\
(\%)\end{array}$ & $\begin{array}{c}\beta \text { carotene } \\
(\mathrm{mg} / 100 \\
\mathrm{g})\end{array}$ & $\begin{array}{l}\text { Ascorbic } \\
\text { acid } \\
(\mathrm{mg} / 100 \\
\mathrm{g})\end{array}$ & $\begin{array}{c}\text { Total } \\
\text { sugar } \\
(\%)\end{array}$ & $\begin{array}{l}\text { Iron } \\
(\mathrm{ppm})\end{array}$ & $\begin{array}{c}\text { Calcium } \\
(\%)\end{array}$ & $\begin{array}{c}\text { Potassium } \\
(\%)\end{array}$ \\
\hline $\mathrm{K}_{0}$ & $9.17 \mathrm{c}$ & $0.050 \mathrm{~d}$ & $14.30 \mathrm{e}$ & $3.62 \mathrm{~d}$ & $23.75 d$ & $0.40 \mathrm{ab}$ & $0.33 c$ \\
\hline $\mathrm{K}_{35}$ & $9.82 b$ & $0.057 \mathrm{c}$ & $19.76 \mathrm{c}$ & $4.45 c$ & $51.03 \mathrm{c}$ & $0.42 \mathrm{a}$ & $0.35 c$ \\
\hline $\mathrm{K}_{70}$ & $10.05 \mathrm{ab}$ & $0.072 b$ & $22.68 \mathrm{a}$ & $4.94 \mathrm{ab}$ & $62.28 b$ & $0.40 \mathrm{ab}$ & $0.39 \mathrm{cb}$ \\
\hline $\mathrm{K}_{105}$ & $10.30 \mathrm{a}$ & $0.090 \mathrm{a}$ & $26.49 \mathrm{a}$ & $5.05 \mathrm{a}$ & $70.77 \mathrm{~b}$ & $0.38 b$ & $0.52 b$ \\
\hline $\mathrm{K}_{140}$ & $9.97 \mathrm{~b}$ & $0.070 \mathrm{~b}$ & $18.77 \mathrm{~cd}$ & $4.71 b c$ & $123.20 \mathrm{a}$ & $0.37 \mathrm{~b}$ & $0.68 \mathrm{a}$ \\
\hline $\mathrm{K}_{175}$ & $9.18 \mathrm{c}$ & $0.057 \mathrm{c}$ & $16.48 \mathrm{de}$ & $3.63 \mathrm{~d}$ & $116.00 \mathrm{a}$ & $0.32 \mathrm{c}$ & $0.71 \mathrm{a}$ \\
\hline $\begin{array}{l}\text { Level of } \\
\text { significance }\end{array}$ & $* *$ & $* *$ & $* *$ & $* *$ & $* *$ & $* *$ & $* *$ \\
\hline $\mathrm{CV}(\%)$ & 1.80 & 11.56 & 7.97 & 4.78 & 9.39 & 21.48 & 8.74 \\
\hline
\end{tabular}

Means bearing same letter (s) do not differ significantly at $1 \%$ level of probability by DMRT

** $1 \%$ level of probability.

\section{$\boldsymbol{\beta}$ carotene}

$\beta$ carotene content of tomato had significantly varied due to the influence of different levels of potassium (Table 2). The maximum $\beta$ carotene $(0.090 \mathrm{mg} / 100$ g) was found in $K_{105}$ and it was followed by $K_{70}(0.072 \mathrm{mg} / 100 \mathrm{~g})$ while the lowest $\beta$ carotene content was found in $\mathrm{K}_{0}(0.050 \mathrm{mg} / 100 \mathrm{~g})$.

\section{Ascorbic acid}

Significant variation was observed of the content of ascorbic acid in tomato due to the effect of different levels of potassium (Table 2). The maximum ascorbic acid $(26.49 \mathrm{mg} / 100 \mathrm{~g})$ was found in $\mathrm{K}_{105}$ which was statistically similar with $\mathrm{K}_{70}$ $(22.68 \mathrm{mg} / 100 \mathrm{~g})$ While it was minimum $(14.30 \mathrm{mg} / 100 \mathrm{~g})$ in of $\mathrm{K}_{0}$. The reason of increased content of ascorbic acid might be that $\mathrm{K}$ played a key role in proper carbohydrates metabolism and formation of ascorbic acid (Majumdar et al., 2000).

\section{Total sugar}

The percentage of total sugar significantly varied due to the effect of potassium (Table .2). The highest content of total sugar $(5.05 \%)$ was found in $K_{105}$ which was statistically similar with $\mathrm{P}_{70}(4.94 \%)$. On the other hand, the lowest total sugar content was found in $\mathrm{K}_{0}(3.62 \%)$. This might happen due to the fact that potassium played a key role in carbohydrate metabolism and photosynthesis and as a consequence, an optimum potassium supply determine better sugar content into sink organs (Marschner, 1995). 


\section{Iron}

Significant variation of iron content of tomato was found due to the effect of $\mathrm{K}$ (Table 2). The highest content of iron $(123.20 \mathrm{ppm})$ was found in $\mathrm{K}_{140}$ which was statistically alike with $\mathrm{K}_{175}(116.00 \mathrm{ppm})$ and it was followed by $\mathrm{T}_{105}(70.77$ $\mathrm{ppm})$ while it was the lowest in $\mathrm{K}_{0}(23.75 \mathrm{ppm})$. It was observed that iron content of tomato increased with the increase of potassium upto $\mathrm{K}_{140}$.

\section{Calcium}

Calcium had significant influence on calcium content of tomato (Table 2). The maximum calcium $(0.42 \%)$ was found in $\mathrm{K}_{35}$ which was statistically similar with $\mathrm{K}_{0}(0.40 \%)$ and $\mathrm{K}_{70}(0.40 \%)$. However, $\mathrm{K}_{105}(0.38 \%)$ and $\mathrm{K}_{140}(0.37 \%)$ showed the intermediate $\mathrm{Ca}$ content and it was lowest in $\mathrm{K}_{175}(0.32 \%)$. The result also indicated that increase of potassium rate decreased the $\mathrm{Ca}$ content. It might be due to the negative interaction between $\mathrm{Ca}$ and $\mathrm{K}$ in tomato. Malvi (2011) reported that $\mathrm{Ca}$ and $\mathrm{K}$ ions are quite similar in size and charge. So, high $\mathrm{K}$ reduces plants ability to absorb $\mathrm{Ca}$ due to their antagonistic nature.

\section{Potassium}

The highest content of potassium $(0.71 \%)$ was found in $\mathrm{K}_{175}$ follower by $\mathrm{K}_{140}$ $(0.68 \%), \mathrm{K}_{105}(0.52 \%)$ and $\mathrm{K}_{70}(0.39 \%)$ while it was lowest in $\mathrm{K}_{0}(0.33 \%)$. It was observed that increased the rate of $\mathrm{K}$ increased the $\mathrm{K}$ content of tomato. Kaviani et al., (2004) reported that increasing the $\mathrm{K}$ level increased the $\mathrm{K}$ uptake in plant.

\section{Response equation}

Regression analysis was done to quantify the relationship of applied potassium with yield $\left(\mathrm{kg} \mathrm{ha}^{-1}\right)$ of tomato. A quardratic relationship between yield and $\mathrm{K}$ was observed (Fig. 2). The estimated relationship reveal that fruit yield would be increased with the application of $\mathrm{K}$ up to $95.31 \mathrm{~kg}$ per hectare and beyond that dose, the yield may be declined. From the regression equation $\left(y=-3.339 x^{2}+\right.$ $636.5 \mathrm{x}+42606$ for $\mathrm{K}$ ) the optimum doses of $\mathrm{K}$ was $95.31 \mathrm{~kg} \mathrm{ha}^{-1}$ and its corresponding yield was $71.96 \mathrm{t} \mathrm{ha}^{-1}$.

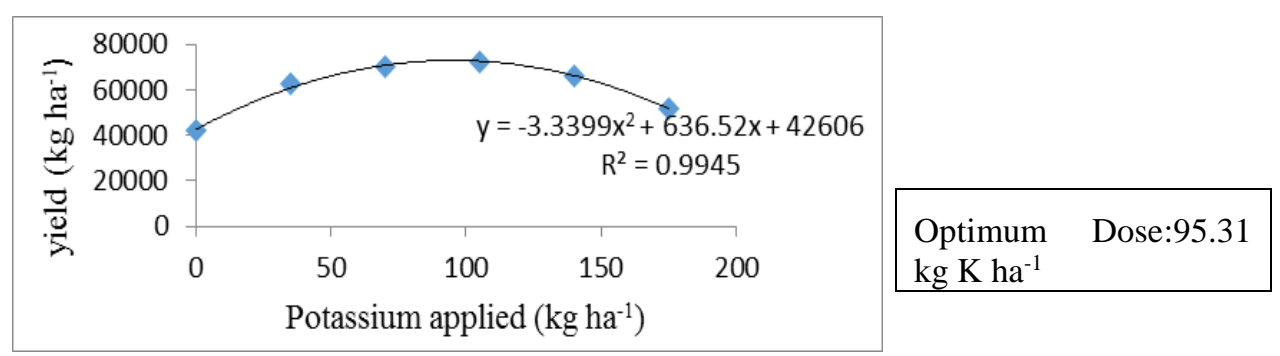

Fig. 2. Response of yield of tomato to potassium fertilizer. 


\section{Conclusion}

The tomato plant treated with potassium @ $105 \mathrm{~kg} \mathrm{ha}^{-1}$ produce maximum plant height, number of fruits plant ${ }^{-1}$, fruit diameter, fruit length, weight of fruit plant ${ }^{-1}$, fruit yield ha ${ }^{-1}$, dry matter, firmness, shelf life, TSS, $\beta$ carotene, ascorbic acid and total sugar. On the other hand, maximum weight loss was found in $\mathrm{K}_{0}$. Iron content increased upto $140 \mathrm{~kg} \mathrm{ha}^{-1}$ and potassium content increased with the increasing level of potassium but reverse effect was found in case of calcium. Based on regression equation, the optimum doses of $\mathrm{K}$ for tomato production was $95.31 \mathrm{~kg} \mathrm{ha}^{-1}$ in salna series of shallow red brown terrace soil.

\section{References}

BBS (Bangladesh Bureau of Statistics). 2013. Year book of agricultural statistics of Bangladesh. Statistics Division, Ministry of Planning, Govt. of the People's Republic of Bangladesh.pp.128-142.

Bhagat S. K., M. S. Islam, A. Ullah, M. H. Akand and A. F. M. J. Uddin. 2014. Consequence of potassium levels on growth and yield of BARI Tomato-14. J. Expt. Biosci. 5(2):7-10.

Cakmak, I. 2005. The role of potassium in alleviating detrimental effects of abiotic stresses in plants. J. Plant Nutr. Soil Sci. 168:521-530.

FAO. 2010. The state of food insecurity in the world: Addressing food insecurity in the protracted crises. Food and Agriculture Organisation of the United Nations, Rome, Italy, pp: 120-140.

FRG. 2012. Fertilizer Recommendation Guide. Bangladesh Agricultural Research Council, Soils Pub.No. 41, pp.113-120.

Grierson, D. and A. A. Kader. 1986. Fruit ripening and quality. The tomato crop. Chapman and Hall, London. pp 240-280.

Hassan, H. K., B. L. D. Chowdhury and N. Akter. 2010. Final report on Post harvest Loss Assessment: A study to formulate policy for loss reduction of fruits and vegetable and socio-economic uplift of the stakeholders. With the support of NFPCSP and USAID, Bangldesh Agriculturl University, Mymensingh, pp. 30-188.

Kaloo, G., 1986. Tomato (Lycopersicon esculentum Miller). Allied Publishers Pvt. Ltd., New Dehli. pp. 203-220.

Kaviani, I., M. Basiral, and M. J. Malakouti. 2004. A comparison between the effect of fertilization and soil application of potassium chloride and Soluble sop on the yield and quality of tomato in Borasian Region of Bonshehv. IPI regional workshop on potassium and fertilization development in west Asia and North Africa. Rabat, Moroceo, Nov. 24-28.

Lester, G. E., J. I. Jifon and W. M. Stewart. 2007. Better Crops. 91:(1)24-25.

Malvi, U. R. 2011. Interaction of micronutrients with major nutrients with special reference to potassium. Karnataka J. Agric. Sci. 24 (1): 106-109. 
Marschner, H. 1995. Functions of mineral nutrients: macronutirents, In: H. Marschner (ed). Mineral nutrition of higher plants 2nd Edition. Academic Press,. N.Y. p. 299-312.

Majumdar, S. P., R. L. Meena, and G. D. S. Baghel. 2000. Effect of levels of compaction and potassium on yield and quality of tomato and chilli crops grown on highly permeable soils. J. Indian Soc. Soil Sci. 48(2): 215-220.

Mazed H. E. M. K., M. H. Akand, M. N. Haque , M.. A. I. Pulok and S. G. Partho. 2015. Yield and Economic Analysis of Tomato (Lycopersicon Esculentum Mill.) as Influenced by Potassium and Stem Pruning. International Journal of Scientific and Research Publications, 5(1): 1-5.

Munson, R. D. 1985. Potassium in Agriculture, ASA - CSSA - SSSA, Madison, Wiscon sin, USA.

Nagata, M., K. Dar and D.I. Yamashita. 1992. Simple method for simultaneous determination of Chlorophyll and Arytenoids in tomato. J. Japan Soc. Hort. Sci. 61(2):686-687. (Supplementary issue).

Piper, C. S. 1966. Soil and plant analysis, Hans Publishers, Bombay (Reprint): pp. 368 392.

Pleshkov, B.P. 1976. Practical Work on plant Biochemistry. Mosco. Kolos, Pp:236-238.

Shukla, V. and L. B. Naik. 1993. Agro-lechniques for Solanaceous Vegetables. In: Vegetable Crops: Part-I, Advances in Horticulture, Vol. 5, Eds: K. L. Chadha and G. Kalloo, Malhotra Publishing House, New Delhi, India. p.37I

Usherwood, N. R. 1985. The role of potassium in crop quality. In: Munson R.D. (ed.) Potassium in Agriculture. Am. Soc. of Agron, Madison, USA. Pp 489-513.

Vanitha, S.M., S.N.S. Chaurasia, P.M. Singh and P.S. Naik. 2013. Vegetable statistics, Technical Bulletin No, 51, HVR, Varanasi, pp, 250. (Published by P.S. Naik, Indian Institute of Vegetables Research, Varanasi, Uttar pradesh). 